\title{
Development and Underdevelopment in the Middle East and North Africa
}

\section{Citation}

Cammett, Melani. 2018. Development and Underdevelopment in the Middle East and North Africa. The Oxford Handbook of the Politics of Development, ed. Carol Lancaster and Nicolas van de Walle. Oxford: Oxford University Press.

\section{Permanent link}

http://nrs.harvard.edu/urn-3:HUL.InstRepos:41467546

\section{Terms of Use}

This article was downloaded from Harvard University's DASH repository, and is made available under the terms and conditions applicable to Other Posted Material, as set forth at http:// nrs.harvard.edu/urn-3:HUL.InstRepos:dash.current.terms-of-use\#LAA

\section{Share Your Story}

The Harvard community has made this article openly available.

Please share how this access benefits you. Submit a story.

Accessibility 


\section{Oxford Handbooks Online}

\section{Development and Underdevelopment in the Middle East and North Africa a}

Melani Cammett

The Oxford Handbook of Politics of Development

Edited by Carol Lancaster and Nicolas van de Walle

Subject: Political Science, Comparative Politics, Political Economy

Online Publication Date: Jan 2017 DOI: 10.1093/oxfordhb/9780199845156.013.25

\section{Abstract and Keywords}

This article examines the trajectories of economic development and underdevelopment in the Middle East and North Africa (MENA). It first considers the empirical record of development in the region, paying particular attention to standard measures of GDP, industrialization, and social development. The article contextualizes the region's development trajectory in a larger set of cross-regional comparisons and looks at the region's record of economic growth and development in different periods after World War II. It also evaluates a number of factors that account for economic performance in the region-such as colonialism, Islam, social relations, corruption and crony capitalism, authoritarianism, and populism-before offering an alternative account. It argues that the MENA's suboptimal economic performance is associated with the particular manifestation of business-government relations in the region.

Keywords: economic development, underdevelopment, Middle East, North Africa, social development, political economy, economic growth, colonialism, Islam, social relations

Home to vast oil reserves, the Middle East and North Africa (MENA) region is associated with immense wealth concentrations. ${ }^{1}$ In reality, the region encompasses countries with widely divergent economic structures and development trajectories, ranging from the oil Gulf monarchies, which boast some of the highest levels of per capita GDP in the world and the most generous social benefits for citizens, to poor countries such as Yemen, where poverty levels are comparable to those of some sub-Saharan African countries (CIA 2013). As the ongoing Arab uprisings have exposed, populations in many MENA countries face great insecurity in meeting their daily needs while high unemployment, particularly among educated youth, is an enormous challenge to development and well-being (ILO 2010; Salehi-Isfahani 2010; UNDP 2009; World Bank 2003a). 


\section{Development and Underdevelopment in the Middle East and North Africa}

While on average the region is not the poorest in the world nor does it exhibit the lowest levels of human development, MENA countries have acquired a reputation as economic laggards. It is widely asserted that the MENA region has failed to develop strong manufacturing bases, while human development lags vis-à-vis regional levels of wealth, and that its most populous countries have not achieved sufficient economic growth rates to address high youth unemployment problems. Across the MENA, countries are characterized by authoritarian rule (which persists in various forms in most countries, even after the Arab uprisings), entrenched crony capitalism, extensive government ownership, and, in some cases, inefficient public enterprises (UNDP 2002, 2009).

Based on a critical review of diverse explanations for underdevelopment in the MENA, ranging from long-run historical approaches to accounts that concentrate on developments since independence, I make two main arguments in this chapter. First, a single framework cannot explain the diverse cross-national economic trajectories because the region includes countries with widely variable natural resource and human capital endowments, while state institutions and state-society relations have evolved differently in countries with distinct levels and experiences of colonial rule and postcolonial stateand nation-building. In fact, the MENA region is composed of three distinct types of economies, which entail different levels of population and natural resource endowments. Second, ongoing research on economic outcomes in the MENA region should pay more attention to colonial legacies and their interaction with postcolonial policies and institutions, and should seek to explain why the particular manifestation of businessgovernment relations in the region seems to be associated with suboptimal economic performance.

The chapter begins by tracing the empirical record of development in the region, focusing on standard measures of GDP and industrialization as well as social-development indicators. The region's development trajectory is contextualized in a larger set of crossregional comparisons to elucidate the ways in which MENA has and has not excelled with respect to economic and social outcomes. The subsequent section provides a basic typology of national political economies in the region, incorporating both political regime type and economic factors as the main criteria for classifying MENA countries. This section traces the record of economic growth and development across the distinct political economies of the region in different periods after World War II. In the remaining parts of the chapter, I assess existing explanations for economic performance in the region, laying the foundation for an alternative account of the diverse economic trajectories within the Middle East. 


\section{MENA Development in Regional Comparative Perspective}

The MENA has acquired a reputation as a relatively underdeveloped region (Kuran 2011; Maddison 2003; Pamuk 2006). From a long-run historical perspective, the region as a whole has declined economically, particularly since the seventeenth century. In the Middle Ages, the region was a site of innovation and prosperity, particularly in comparison with Europe, which was undergoing a protracted slump following the collapse of the Byzantine Empire. By the eighteenth century, however, the MENA lagged behind Europe, which had become a global economic and military powerhouse. Furthermore, European powers were exerting increasing pressure on the Ottoman Empire, which ruled much of the Islamic world from roughly the thirteenth century to the early twentieth century. While the Ottoman government was mired in debt and economically stagnant, European powers were dividing up much of what is now the global South through competing colonialist projects. By the early nineteenth century, growth rates in the MENA were less than half those in the West (see Figure 1).

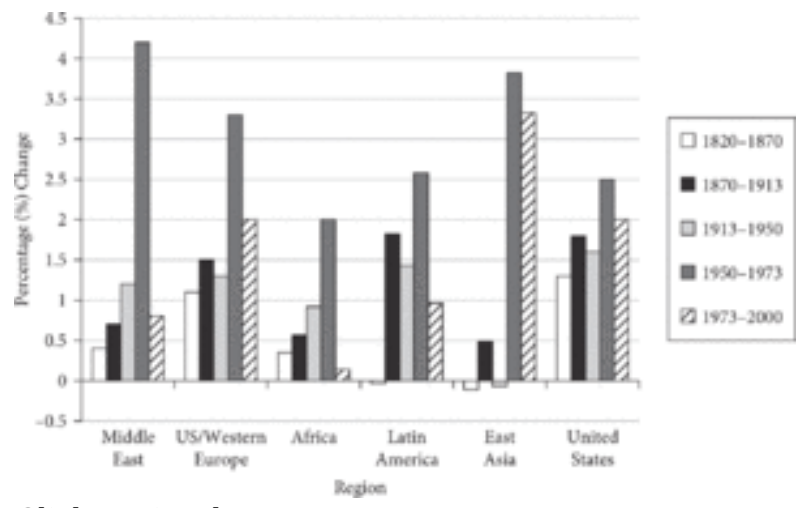

Click to view larger

Figure 1: Cross-Regional Growth in Per Capital GDP (\% Change), 1820-2000

Sources: Maddison (2003); Pamuk (2006).
A cross-regional comparative lens, however, casts doubt on an overly negative depiction of MENA economic development trajectories. Economic decline vis-à-vis Europe is hardly unique to the Middle East or North Africa; in comparison with other developing regions that were also subject to European colonialism, the MENA region does not

fare poorly. As Figure 1 shows, the MENA exhibits consistently higher growth rates than sub-Saharan Africa and, for 1950 to 1970, than Latin America. Arguably, these regions are more appropriate regional comparators than East Asia, which experienced exceptionally high and sustained growth rates in the second half of the twentieth century.

Nonetheless, the MENA region as a whole-and especially particular subregions within it -stands out vis-à-vis other developing regions with respect to several factors: First, the region has exhibited more volatile growth trends than other developing regions, especially among the more populous countries with large oil endowments such as Algeria, Iraq, and Iran. ${ }^{2}$ Despite strong growth during the 1960s and 1970s across the region, MENA countries then experienced a protracted slowdown. In the past three decades, the region has had lower growth rates than East and South Asia and, for some periods, 
displayed lower and more erratic growth rates than Latin America and sub-Saharan Africa. Although most MENA economies reduced their budget deficits and inflation in the 1990s, growth rates stagnated and the region's economies remained vulnerable to fluctuations in oil prices (Nugent and Pasaran 2007, pp. 14-15; UNDP 2002). Such low and volatile growth rates are disappointing given the rich natural resource endowments and high levels of foreign aid and remittances in the region- although, as I discuss subsequently, access to external rents may help to explain economic trends in some countries in the region.

Second, levels of industrialization, which are associated with high-growth political economies and are therefore widely viewed as a key dimension of economic development, also point to the relative underdevelopment of the MENA region. As Figure 2 shows, the MENA stand out for poor levels of industrial development as measured by value added from manufactures as a percentage of GDP.

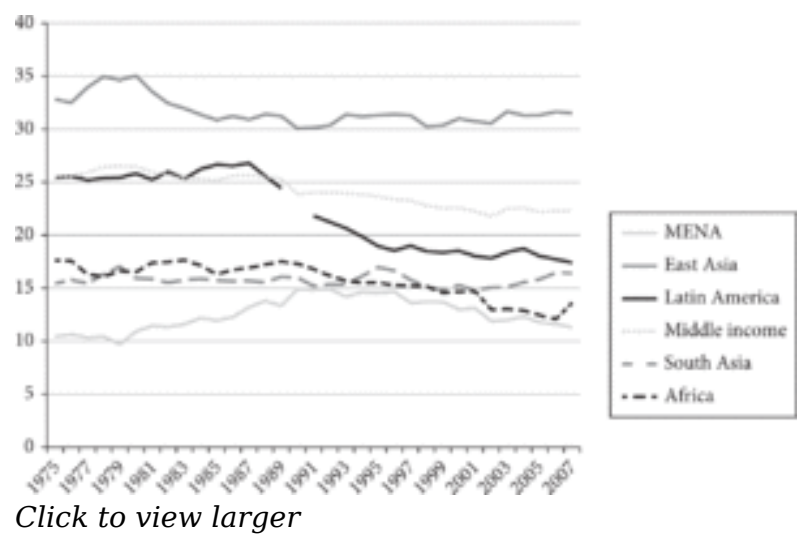

Figure 2: Manufacturing Value Added as a Percentage of GDP for Selected Regions (Developing Countries Only), 1975-2007

Source: World Bank, World Development Indicators (Washington, DC: World Bank, various years).
In 1975, during the golden age of postindependence prosperity, manufactured exports as a percentage of GDP amounted to about 10.4 percent in the MENA region, as compared to 15.4 percent in South Asia, 25.4 percent in Latin America, and 32.8 percent in East Asia, among the developing countries of each region. By 2007, manufactured exports remained relatively low in

the MENA region (11.3 percent) when compared to 16.4 percent in South Asia, 17.6 percent in Latin America, and 31.6 percent in East Asia (World Bank, World Development Indicators [Washington, DC: World Bank, various years]). At the same time, the region now faces global economic challenges facing virtually all developing regions. With the collapse of the prices of manufactured goods and the rise of China and India as export powerhouses, industrialization is no longer a viable strategy for development for most regions. Because nontradables are the key drivers for growth in the advanced industrialized economies, the position of most developing countries is tenuous in the evolving global economy. Of course, global economic constraints in the current period do not explain why the region could not take advantage of export opportunities in prior decades, as other regions were able to do.

Third, by some measures, the MENA region has also lagged in recent years with respect to human development, a critical measure designed to capture the ways in which populations actually experience socioeconomic change. Figure 3 depicts cross-regional 


\section{Development and Underdevelopment in the Middle East and North Africa}

levels of human development over time. ${ }^{3}$ As the figure shows, on aggregate the MENA outperforms South Asia and sub-Saharan Africa with respect to human development, but consistently lags behind Latin America and, since the mid-2000s, East Asia. This is striking given that the MENA region is home to some of the wealthiest countries in the world, with Qatar ranking first globally in terms of per capita GDP (IMF 2013), confirming the oft-stated claim that income does not guarantee human development (Sen 1999; UNDP 1994).

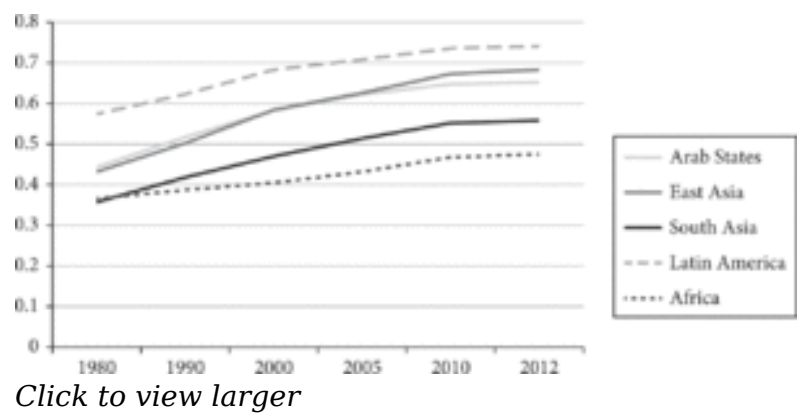

Figure 3: Human Development Index (HDI) Values by Region, 1980-2012

Source: http://hdr.undp.org/en/data
Finally, as the Arab uprisings have underscored, the Middle East faces seemingly intractable challenges to employment generation. Unemployment, particularly among educated youth, is higher in MENA than any other global region (ILO 2010). In the face of the global

recession and structural features of their economies, virtually none of the countries in MENA seem able to generate sufficient growth rates to absorb unemployment in the short to medium term (World Bank 2003b; Salehi-Isfahani 2010). As a result, the MENA region essentially forfeited the opportunity to take advantage of the "demographic gift" of a young population (Karshenas and Moghadam 2006, pp. 12-13). To the contrary, the region experienced a youth population bulge at precisely the moment when it underwent economic adjustment and a reduction in growth rates. ${ }^{4}$ In addition, low female labor-force participation rates have undercut the region's productive potential. Indeed, women constitute the smallest share of the workforce in the Middle East and North Africa when compared to other regions. ${ }^{5}$

In sum, the MENA region has become associated with economic underperformance. This reputation, however, is only partially deserved. Fist, in cross-regional comparative perspective, the region as a whole has performed reasonably well. Second, as I discuss more subsequently, the MENA region cannot be treated as an aggregate because distinct subgroups of economies have dramatically varied resource endowments and have exhibited markedly distinct development paths. As a result, blanket explanations for regional underdevelopment are problematic.

Notwithstanding these important objections to region-wide claims, the depiction of economic underperformance in the Middle East and North Africa persists. Various editions of the Arab Human Development Report (UNDP 2002, 2004, 2009), a publication researched and written by Arab researchers and published by the UNDP, emphasize that the region suffers not only from low levels of per capita income relative to its wealth, but also declining productivity, underdeveloped research capabilities, levels of illiteracy, poor 
health and educational outcomes in comparison with countries of comparable income levels, gender inequality, and persistent authoritarianism. Despite debates about the political underpinnings of these claims (Abu-Lughod 2009; Bayat 2005) and the appropriateness of cross-regional comparative benchmarks (Owen 2002), there is broad consensus among scholars and policy-makers within and outside of the region that the well-being and socioeconomic opportunities of citizens of MENA countries are deficient. Beyond objective indicators, core demands for dignity and social justice in the Arab uprisings indicate that many citizens perceive that their governments have failed them economically.

\section{Varieties of MENA Political Economies and Postindependence Development Trajectories}

Any attempt to account for patterns of development and underdevelopment in the MENA region must begin by acknowledging its distinct subtypes of political economies. Based on resource endowments alone, the region can be divided into three distinct types of economies, including countries with low populations and high wealth from oil and other natural resources (i.e., Bahrain, Kuwait, Libya, Oman, Qatar, Saudi Arabia, and the UAE); those with high populations and high oil wealth (i.e., Algeria, Iran, and Iraq); and those with no or minimal oil wealth on a per capita basis (i.e., Egypt, Jordan, Morocco, Syria, Tunisia, Turkey, Yemen). At a minimum, variation across subtypes of regional political economies calls into question sweeping explanations of region-wide economic trends.

Oil wealth is the most obvious point of differentiation among MENA political economies and is either positively or negatively associated with other key development indicators such as per capita GDP, industrialization, and human development. All high-income countries-Bahrain, Kuwait, Oman, Qatar, Saudi Arabia, the UAE, and Libya ${ }^{6}$-have high levels of oil dependence ${ }^{7}$ and relatively small indigenous populations. Countries with high oil dependence and large populations, such as Algeria and Iran, however, fall in the lower middle-income group despite their valuable natural resource endowments. The remaining middle-income countries export a relatively low volume of hydrocarbons or none at all.

Oil can bring spectacular wealth; however, it is also central to some explanations for MENA underdevelopment. High oil dependency is negatively associated with industrialization and, as a result, may impede economic development in the longer term (Beblawi 1987; Ross 2012; Sachs and Warner 2001). ${ }^{8}$ None of the region's top exporters of manufactured goods, including Turkey, Tunisia, Jordan, Morocco, and Egypt, have significant oil endowments, while the major oil exporters, such as the Gulf states, Libya, and Algeria, have lower levels of industrialization (World Bank 2013). 
Although it may deter industrialization, oil wealth-the primary historical path to development-can buy relatively high quality of life, as captured by intraregional differences in human development levels (see Figure 4). All MENA countries that achieve "high" or "very high" ratings on the UNDP Human Development Index (HDI) are lowpopulation oil exporters (Malik 2013). A cross-regional perspective, however, highlights the fact that wealth does not automatically translate into superior scores on all dimensions of human development. For example, the UAE and Portugal have comparable HDI scores (.818 and .816, respectively), yet the former's GDP per capita is nearly twice that of the latter country. Kuwait's HDI value of .790 is slightly lower than that of Uruguay, yet its GDP per capita $(\$ 52,793)$ is nearly four times larger (Malik 2013). Within the Middle East, some countries, such as the West Bank and Gaza, have higher literacy rates than their income levels would predict, in part thanks to social practices that value education as a key source of upward mobility. To some degree, oil has shaped the economies of all countries in the region, irrespective of natural resource endowments, by fueling regional flows of labor remittances, aid, and, to a lesser degree, private investment (Pfeifer 2012).

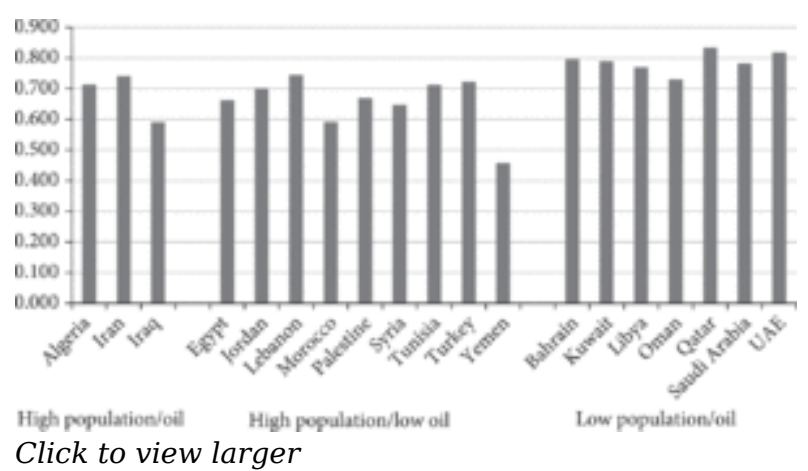

Figure 4: HDI Values across the MENA Countries

Source: http://hdr.undp.org/en/data
Economic and social indicators alone, however, provide an incomplete perspective on the variety of political economies in the region and overlook some of the key political factors that are sometimes invoked to explain underdevelopment in the region, namely regime type and patterns of

governance. The formal and informal rules determining the allocation of political power shape the formulation of economic and social policies as well as the strategies that labor, business, and other key social groups adopt to adjust to economic change. With the exceptions of Turkey and, to a lesser degree, Lebanon, Iran prior to 2005, and now perhaps Tunisia and Libya after the Arab uprisings, virtually all MENA countries are characterized by relatively unchecked executive power and limitations on political and civil liberties (Posusney and Angrist 2005). Most countries are classified as monarchies or single-party republics, although within these distinct regimes types, the structure of representation and informal patterns of state-society relations vary. Furthermore, different political economies are associated with distinct types of social contracts or with varying commitments of rulers to provide for citizens in exchange for political support as institutionalized in postindependence constitutions, laws, and political rhetoric (Youssef 2004, p. 92). 
A typology of MENA countries based on oil endowments and regime type captures important sources of variation in the countries of the region (see Table 1). In general, different political economies-oil monarchies, non-oil monarchies, oil republics, non-oil republics, and democracies and quasi-democracies-are associated with different strategies of economic development and redistribution. In part because of varied resource endowments and, more importantly, because of different strategies of legitimation, rulers in these diverse political economies adopted distinct development rhetoric and even policies.

\begin{tabular}{|c|c|c|}
\hline & Oil & Non-Oil \\
\hline Monarchies & $\begin{array}{l}\text { Bahrain, Kuwait, Oman, Qatar, Saudi } \\
\text { Arabia, UAE, Iran (pre-1979) }\end{array}$ & Jordan, Morocco \\
\hline Republics & Algeria, Iraq (pre-2003), Iran (2005-) & $\begin{array}{l}\text { Egypt (1952-2011), Syria, } \\
\text { Tunisia (1956-2011) }\end{array}$ \\
\hline $\begin{array}{l}\text { Democracies/ } \\
\text { Quasi- } \\
\text { Democracies }\end{array}$ & Libya (2011-), Iran (1979-2005) & $\begin{array}{l}\text { Egypt (2011-2013), } \\
\text { Lebanon, Turkey, Tunisia } \\
\text { (2011-), Iraq (2003-) }\end{array}$ \\
\hline \multicolumn{3}{|c|}{$\begin{array}{l}\text { * Libya prior to } 2011 \text { defies easy categorization given Colonel Muammar Qadhafi's } \\
\text { construction of a unique regime type, the Jamahiriya, which was theoretically a form of } \\
\text { direct democracy without political parties in which administration occurred through } \\
\text { popular councils. In practice, the system was authoritarian and reserved extensive } \\
\text { discretionary power for Qadhafi and his allies. }\end{array}$} \\
\hline
\end{tabular}

More broadly, any typology of MENA political economies should move beyond economic determinism and classifications based on formal regime type to highlight the importance of "institutional quality." 9 The nature of governance as manifested in specific institutions that structure property rights and define state regulatory capacity, among other factors that contribute to well-functioning markets, is increasingly linked to economic performance (Acemoglu, Johnson, and Robinson 2005; Chaudhry 1993; North 1990). As discussed subsequently and developed more fully in the chapter by James Robinson in this volume, the scholarly literature on development increasingly points to the long-run historical determinants of governing institutions, which in turn shape development outcomes that persist for decades if not centuries in most cases (see, inter alia, Acemoglu, Johnson, and Robinson 2002; Diamond and Ordunio 1997; Engermann and Sokoloff 2002; Kaufmann, Kraay, and Mastruzzi 2009; Mahoney 2010; Sachs and Warner 1997). 


\section{Development and Underdevelopment in the Middle East and North Africa}

How have overall economic development strategies evolved in the diverse subgroups of political economies in the MENA region? Most of these countries did not become independent states until the mid-twentieth century, when the British and French colonial powers withdrew. Among the first orders of business for postindependence elites was economic development and the establishment or consolidation of national market institutions. In the decades since independence and despite some shared colonial legacies, MENA economies developed in distinct ways. Broad patterns of variation are visible across the different subtypes of political economies outlined in Table 1.

In the postwar period, the more populous countries in the MENA region-like many countries in other developing regions-adopted import-substitution industrialization (ISI) policies, fostering the rise of a domestic industrial bourgeoisie and local industrial working class that benefited from populist policies such as consumer-price subsidies on staple goods. At the same time, the public sector grew dramatically, with the establishment of state-owned enterprises in all MENA political economies as well as vast public investment (Richards and Waterbury 2008, ch. 7). The single-party republics went farthest in adopting ISI policies, constructing state-owned enterprises (SOEs) and marginalizing the private sector (Richards and Waterbury 1996, p. 180). For varying durations, all of the single-party republics adopted versions of populist, quasi-socialist strategies of legitimation at independence, including Egypt (1957-1974), Algeria (19621989), Syria (1963-1990s), Iraq (1963-1990s), and Tunisia (1962-1969). ${ }^{10}$ The new leaders of the republics also instituted land-reform policies and developed or expanded public health and education systems. The most extensive entitlements were reserved for formal sector workers, who constituted a relatively small portion of the total work force. With postcolonial nationalizations and the establishment of state-owned enterprises, civil service and parastatal workers gained job security and a range of social protections, but, in exchange, were expected to be politically docile. The republics varied in the extent to which they made populism and "Arab socialism" (Richards and Waterbury 1996, p. 181) the centerpiece of their rhetoric and actually instituted populist policies. Egypt under President Gamal Abdel Nasser (1956-1970) exhibited a particularly strong commitment to populism, while Tunisia turned away from its quasi-socialist experiment earlier than other republics. In the case of Algeria, oil wealth greatly aided populist policies, particularly during spikes in world oil prices, postponing the high debt burden that tends to arise with ISI strategies.

The republics, including Algeria, Syria, and (until 2011) Egypt and Tunisia, have all been characterized by single-party rule, in which a dominant party controls political life and permeates most elements of society and associational life. In both the oil and non-oil single-party republics, the formal representation of economic interests, including labor and business, was or remains highly centralized, facilitating state control (Bellin 2002; Cammett 2007; Cammett and Posusney 2010; Gobe 1999; Haddad 2004; Sfakianakis 2004). Until the Arab uprisings, the republics generally permitted fewer political and civic freedoms than the monarchies. 


\section{Development and Underdevelopment in the Middle East and North Africa}

In the region's kingdoms, both the structure and practice of politics vary significantly, particularly across the oil and non-oil countries. During the colonial era, all of the Gulf principalities apart from Saudi Arabia became British protectorates and were ruled only nominally by their traditional tribal sheikhs. As these countries gained independence and modernized in the 1960s and early 1970s, ruling families consolidated their power (Herb 1999). The Gulf monarchies generally exercise strict control over societal expression, and all officially ban political parties ${ }^{11}$ and prohibit the formation of labor unions, although some have recently modified this policy (Cammett and Posusney 2010). In the Gulf monarchies, societal opposition to authoritarian rule is relatively limited, in large part due to generous social transfers sustained by oil and gas revenues. Patronage and discretionary access to economic opportunities has created a loyal client base (Herb 1999). While the Gulf monarchies score poorly in measures of "voice and accountability," a key feature of democratic rule, their measures of the rule of law and control of corruption are higher than most other countries in the region (Kaufmann, Kraay, and Mastruzzi 2009), compelling investors to deem them more reliable sites for investment and conducting business than other economies in the region (World Bank 2011). ${ }^{12}$

With oil dominating their economies and with minimal or no manufacturing bases beyond joint ventures with foreign companies in petrochemicals, there was little need to adopt protectionist trade regimes in the Gulf economies. Furthermore, with the exception of Saudi Arabia, the indigenous population was too small to warrant an ISI approach, which requires a substantial domestic consumer base and labor force. The weight of the public sector in the economy, however, surpassed that of the non-oil countries thanks to windfall oil profits, especially after the oil shocks of the 1970s (Chaudhry 1997; Crystal 1995).

Political authority and economic policies were institutionalized differently in the oil-poor kingdoms of Jordan and Morocco. In both countries, monarchs exercise tight social control, but have permitted more pluralism than in the Gulf, even prior to the recent Arab uprisings. Although the extent of political freedoms should not be exaggerated, the Jordanian and Moroccan monarchies have permitted diverse parties and independent candidates to contest elections and win seats in parliament (Leveau 1985; Ryan 2002; Zartman 1990). Multiparty politics permits marginally greater scope for the transmission of societal interests to decision makers and even for circumscribed opposition to state policies. From their establishment as independent states, Jordan and Morocco adopted liberal economic rhetoric, which privileged the private sector as the driver of development (Cammett 2007; Henry and Springborg 2010; Moore 2004). ${ }^{13}$ Unlike the single-party republics, the non-oil monarchies did not emphasize populist ideologies, although they instituted some redistributive policies, particularly for formal-sector employees. Accordingly, Jordan and, especially, Morocco adopted less expansive social programs than the Gulf monarchies and left greater room than the single-party republics for nonstate actors to address the social needs of the population. As a result, by some measures, the economic climates in Jordan and Morocco are deemed more favorable to investors than in the republics (World Bank 2011; Kaufmann, Kraay, and Mastruzzi 2009). 


\section{Development and Underdevelopment in the Middle East and North Africa}

Finally, in the democracies and quasi-democracies, no shared pattern has emerged with respect to the organization of the economy and state-society relations due to variation in state-building processes and the relative strength of different social groups. Lebanon's powerful merchant interests and fragmented sectarian power-sharing system have cemented a "laissez-faire" economy with minimal state regulation (Gates 1998). Conversely, in postrevolutionary Iran, direct and indirect state control over the economy was consolidated with the nationalization of most banks and the establishment of bonyads, or foundations, involved in both production and social provision and headed by religious leaders, although important components of the leadership maintain strong support for private enterprise and property rights (Henry and Spingborg 2010, p. 214: Owen 1992, pp. 157-158). In Turkey, interest groups have enjoyed relative freedom to organize, except during periods when the army suspended democracy (Owen 1992, pp. 155-156). Since the 1980s, the Turkish state under distinct administrations has pursued economic liberalization policies, and export business interests have developed substantially alongside preexisting domestic elites. Despite the relative openness of the political system, particularly in Lebanon and Turkey, the democracies do not outshine the Gulf oil monarchies with respect to rule of law, control of corruption, or the ease of doing business (World Bank 2011; Kaufmann, et al (2009).

By the late 1970s and early 1980s, the golden age of growth had stalled in the MENA region. Countries that had adopted ISI policies experienced balance-of-payments crises, which in part explain their adoption of economic reforms supported by international financial institutions. ${ }^{14}$ The signing of EU trade agreements further compelled some MENA countries to open their economies. The actual record of economic reform has varied from country to country. In general, the international financial institutions regard Morocco, Jordan, and, especially, Tunisia as more "successful" cases of economic reform, while Egypt is depicted in more qualified terms (Richards and Waterbury 2008, pp. 239241; Rivlin 2001, pp. 101-114, 128-130).

Economic liberalization has had a mixed record at best in the MENA region. Throughout the region, economic reforms have not produced sustained high growth rates, while inequality has increased somewhat according to official data (World Bank, World Development Indicators [Washington, DC: World Bank, various years]). ${ }^{15}$ Growth rates have been erratic, particularly in Jordan, which is especially vulnerable to regional conflict, and Morocco, which is highly sensitive to drought, among other factors. Economic restructuring has generally come with enormous social costs (Richards and Waterbury 2008; Rivlin 2001). Political and economic elites, who enjoy close ties to rulers -whether presidents or monarchs-have benefited disproportionately from the new opportunities generated by greater global economic integration and increased emphasis on private sector-led development (Cammett and Diwan 2013; Henry and Springborg 2010; Heydemann 2004). 


\section{Explaining Underdevelopment in the Middle East and North Africa}

Economists generally agree on the proximate causes of underdevelopment in the Middle East and North Africa, including weak integration in the global economy, low levels of investment, lack of technology transfer, industrial noncompetitiveness, high levels of government ownership and investment, the low quality of education, and the high costs of doing business (Noland and Pack 2007, p. 11). But these factors are symptoms of deeper causes. A growing scholarly literature offers varied and often competing explanations for persistent underdevelopment in the MENA region. These accounts range from cultural characteristics and entrenched historical legacies to the "curse" of natural resource endowments and postwar patterns of state-society relations.

\section{Islam and Economic Development}

The countries of the Middle East and North Africa are predominantly Muslim, although religious minorities are important both demographically and politically in some countries. Accordingly, Islam has been blamed for a variety of ills that are said to impede capitalist economic development, including unresponsive authoritarian governments, obstacles to independent reasoning, and the absence of a rational secular mindset (Lewis 1982; Weber 2009; also see Noland and Pack 2007, p. 10). ${ }^{16}$ In general, such accounts are difficult to prove or disprove; therefore, this genre of explanation has not relied on empirical tests. If features of Islam as a religion explain economic underperformance, then cultural shifts should correspond to periods of economic change, and Islamic and non-Islamic societies should exhibit marked differences in economic trajectories and outcomes. The empirical record, however, belies such broad culturalist accounts, which tend to neglect variation in political, social, and economic practices, downplay the capacity of cultures to evolve, and cannot account for the fact that economic growth is variable over time while culture and religion evolve more slowly. If "culture" refers to informal institutions and social practices, however, such explanations may be more compelling, particularly if applied to specific localities rather than to entire regions such as the Middle East or the Islamic world.

A more nuanced line of argumentation in the culturalist vein focuses on the effects of Islamic institutions on the long-term development trajectories of Muslim societies. In a recent book and related articles, Kuran $(2003,2004,2011)$ argues that specific Islamic institutions, notably inheritance laws, marriage regulations, trusts, and contract systems came to inhibit capital accumulation in the Middle East. By dividing up inheritance among multiple family members, channeling resources into social services rather than productive investment, and deterring innovation and flexibility in corporate forms, 


\section{Development and Underdevelopment in the Middle East and North Africa}

Islamic societies were disadvantaged vis-à-vis Europe in developing the kinds of commercial institutions needed for longer-term growth.

Kuran explicitly rejects the claims that underdevelopment is due to flaws within Islam as a religion and or to an alleged fatalism or submission to authoritarian rulers among its adherents. Rather, he argues that Islamic societies were innovative and ahead of their times in creating flexible institutions to facilitate exchange, but that these institutions failed to adapt to new economic and social conditions.

The focus on Islamic institutions advances the study of underdevelopment in the MENA region substantially and brings studies of development in the region in direct dialogue with broader debates about the long-run institutional determinants of growth and development (Acemoglu, Johnson, and Robinson 2002; Engermann and Sokoloff 2002; Sachs and Warner 1997). At least two major critiques, however, point to potential problems in Kuran's linkage between Islamic institutions and economic underdevelopment. First, empirical realities potentially undercut the logic and validity of the argument. Although Kuran acknowledges flexibility inherent in different Islamic schools of law regarding corporate partnerships and charitable trusts (awqaf), the opportunity to adopt distinct corporate institutional forms is not integrated in his argument. Yet the very real empirical possibility that Islamic rulers and traders could have adopted distinct institutional arrangements implies that low demand for institutional flexibility rather than a lack of supply explains institutional stagnation in the Islamic world (Çizakça 2010; Ibrahim 2011, pp. 2-3).

This point suggests a second, more important, critique of Kuran's account of economic stagnation in the Middle East. Rather than institutional features of Islam, the practices and policies of the Ottoman state may explain underdevelopment. As a highly centralized and "strong" state, the Ottomans blocked the rise of an independent civil society and private sector, while their economic policies emphasized social welfare over growth. ${ }^{17}$ As Çizakça (2010) argues, "Kuran recognizes that the European corporation flourished when central authority weakened following the demise of the Roman Empire [p. 103] but fails to contrast this with the situation in the Middle East, where the opposite was taking place and the region was militarizing in response to the Crusades." 18

Furthermore, claims about the long-run effects or Islamic or Ottoman institutions may be overly aggregated, setting up sweeping generalizations across vast stretches of territory. Variation in economic outcomes both during and after Ottoman rule may correlate with divergence in the degree of Ottoman state control across the empire (Haj 1997; Pamuk 1992, 2006). Notwithstanding these critiques, Kuran advances the study of development in the Middle East in important ways by shifting the focus to the impact of institutions on long-term economic trajectories, an area of research that deserves more attention and integrates the entire MENA region more directly in debates about development. 


\section{Social Relations and Long-Run Institutional Development}

An alternative perspective on the long-run sources of relative economic underperformance in the MENA region finds the sources of the divergence between the region and Western Europe not in religion or religious institutions, but rather in relations between rulers and elites. Blaydes and Chaney (2013) locate the rise of growth-enhancing institutions such as property rights, political stability, and accountability in the rise of feudalism in the West. In contrast, the MENA region failed to develop similar patterns of social relations, which accounts for the relative lack of institutions and practices conducive to longer-term economic development, among other outcomes. In particular, the authors contend that the use of military slaves from non-Muslim lands rather than local military conscripts freed Ottoman rulers from the need to bargain with landed elites, which in turn generated arrangements to secure property rights and check the power of rulers.

Like Kuran (2011), Blaydes and Chaney (2013) make an important contribution by bringing research on the Middle East in direct dialogue with contemporary research on long-term economic trajectories, using rigorous empirical methods to support their arguments. Social dynamics across the Muslim world, however, call into question the empirical validity of their claims. The core argument rests on the idea that rulers in Muslim empires did not need to bargain with their subjects because they imported loyal slaves to serve in the military and other government institutions. Yet it is well documented that rulers granted military slaves generous tax farms, who in turn accumulated resources and used them to purchase land that they passed on to their children. Through wealth accumulation, then, these imported slaves settled and acquired the potential to challenge the sultan. Why, then, did they not challenge rulers, as Blaydes and Chaney argue? In fact, the historical experiences of the Mamluks in the twelfth century and, much later, the Janissaries in the Ottoman Empire suggest that foreign military slaves were not always loyal but rather posed a serious threat by rising up periodically against their rulers (Karpat 2010, pp. 32-33; Murphy 1999, pp. 30-32). More generally, it is unlikely that social relations remained stable or operated uniformly in an empire that spanned 600 years and vast stretches of territory. The Ottoman Empire underwent multiple periods of change and reform initiatives over the course of its history, including with respect to the ways in which the Ottomans staffed and managed their military machines (Murphy 1999; Pamuk 2006). ${ }^{19}$

Approaches that seek the roots of economic underperformance in institutions that emerged over a millennium ago (Blaydes and Chaney 2013; Greif 2006; Kuran 2011) purposefully downplay the impact of changes during the colonial and postcolonial periods; at a minimum, they neglect possible interaction effects of these institutions with developments in these periods. To justify this position, Kuran (2011) notes that the roots of economic decline precede these historical periods by centuries. As I will discuss, however, European colonialism and the policies adopted by independent regimes constituted important junctures in development trajectories, sometimes to the detriment 
of economic growth in the MENA region. Furthermore, long-run historical explanations of contemporary economic outcomes face challenges in elucidating the mechanisms by which institutions established centuries ago were reproduced over long time periods and continue to shape development paths and outcomes.

Furthermore, within the Islamic world, there is variation in growth rates. Middle Eastern countries such as Egypt and Jordan have experienced volatile growth rates in a relatively short time frame, while countries such as Indonesia and Malaysia, which are also predominantly Muslim, have enjoyed sustained periods of high growth. More broadly, econometric research indicates that Muslim countries are not associated with poor growth-in some instances, they even exhibit higher growth rates than non-Muslim countries (see Noland and Peck 2007, pp. 143-144). Other research shows that the share of zakat, or obligatory Islamic charitable giving, in total income and the share of Islamic financial institutions in the financial sectors of the Middle East and North Africa as a whole are small and therefore unlikely to hurt economic performance in the aggregate (Pryor 2006). ${ }^{20}$ Nonetheless, arguments meant to apply to vast stretches of territory cannot easily explain variation within these domains. At best, Islamic institutions or patterns of state-society relations established centuries ago interact with other factors at lower levels of analysis.

The fact that other, non-Islamic regions face similar if not worse economic challenges than the Middle East and North Africa, however, suggests that something other than institutions specific to the Islamic world is a key cause of underdevelopment in this and other regions in the global South. For example, many sub-Saharan African countries that are not predominantly Muslim and did not have the same patterns of relations between local rulers and subjects exhibit equal if not worse growth and human-development outcomes. With distinct historical institutional legacies, these countries have also performed poorly. This implies that other factors common to the MENA region and subSaharan Africa (as well as South Asia) may have shaped poor development outcomes in these regions. These might include the effects of colonialism on state development; the reactive, anticolonial policies adopted by nationalist rulers in the postindependence period; and superpower rivalries, which brought access to strategic rents.

\section{Colonialism}

Although a long-term perspective holds that European control over Ottoman lands was a function of economic decline and therefore postdates economic stagnation (Kuran 2011), the nature of colonial involvement in the region had lasting effects on economic development and, particularly, patterns of industrialization in the region.

During the late Ottoman period, some regions and communities in the Ottoman Empire were increasingly integrated in the global economy, in part through the capitulations, or preferential relationships between minority communities and European governments. 
Colonial rule integrated these territories more directly in global markets controlled by European powers and laid the foundations for the creation of national economies with fixed borders, national systems of taxation, and tariffs and other trade barriers. With the fall of the Ottoman Empire and the establishment of the Republic of Turkey in 1923, European colonial powers took direct control of much of the region, establishing British control over Iraq, Palestine, and Transjordan, and French control over Syria and Lebanon. The territories of the Gulf were loosely ruled by prominent families and tribal leaders, and, with the exception of Saudi Arabia, were largely under British control through a series of treaties signed in the late nineteenth and early twentieth centuries. In North Africa, colonial rule was much longer, with the occupation and subsequent incorporation of Algeria into France in 1830 and the establishment of French protectorates in Morocco and Tunisia in 1913 and 1881, respectively.

The colonial period had important legacies for subsequent development trajectories and, in some areas, laid the foundations for a nascent industrial sector. Whether British or French, colonial authorities tended to dominate large-scale manufacturing, invested little in local economies, and devoted few resources to welfare and public works, and local economies remained heavily agrarian and low-income. ${ }^{21}$ Although the colonized protostates were expected to balance their own budgets, colonial domination granted little or no indigenous control over economic policy-making, permitting few protective trade barriers to spur the rise of local industry and exposing local economies to global market fluctuations. ${ }^{22}$ Throughout the region, colonial authorities adopted strategies of indirect rule through alliances with tribal elites and large landowners-a type of colonial administration that has been associated with poorer development outcomes because it does not foster the emergence of effective governing institutions (Boone 1994; Lange 2009; Mamdani 1996).

Despite these shared general patterns, the precise forms of colonial involvement varied across the region. The French invested most heavily in North Africa, where they established significant settler communities, especially in Algeria. Although the North African economies remained dependent on France and granted preferential treatment to French investors and workers, the colonial authorities also invested in local infrastructure and public services. To the east, the British and French colonial authorities did not own land nor did they establish resident communities to the same degree. In Egypt, which the British effectively controlled after 1881, colonial economic interests centered mainly on cotton exports. In Jordan, little industrial and agricultural development occurred, while the discovery of oil in Iraq in the 1930s did little to stimulate industrialization. In Syria and Greater Lebanon, the French established close ties with Maronites and other Christian groups, but colonial investment did not benefit the bulk of the population. In Palestine, the influx of Jewish settlers, some of whom came with high skills and education, as well as material support from Britain enabled the Jews in Palestine to construct a relatively prosperous and industrially developed subeconomy within the British mandate. In Arab areas, however, infrastructure was generally less 
developed, while agricultural techniques were not as productive and industrial development lagged. The Gulf sheikhdoms had virtually no manufacturing base nor agricultural production apart from date harvesting, while significant royalties from oil production did not come until the 1940s.

Unlike most Arab countries, Turkey and Iran $^{23}$ were never directly colonized by the European powers, although capitulations and high foreign debt fostered dependence on Europe. After the establishment of an independent state in 1923, the Turkish government promoted domestic industry through subsidies and protective barriers, generating a relatively developed industrial base by the eve of World War II. In Iran, the Pahlavi monarchy embarked on a nation-building initiative, which entailed the growth of the state bureaucracy and military and the establishment of public enterprises in diverse industries (Owen 1992, pp. 117-118).

This brief overview suggests that variable patterns of colonial investment and governing institutions generated distinct starting points for postindependence MENA countries. Although substantial research points to differences in investment and industrialization under colonial rule (Owen 1993; Owen and Pamuk 1999), few studies systematically explore how the economic legacies of colonialism shaped postindependence growth and development in the region. For example, French control over Algeria was far more comprehensive than in the neighboring French protectorates of Morocco and Tunisia, which may partially account for variation in postindependent economic outcomes in North Africa such as Algeria's particularly erratic patterns of economic growth. Furthermore, the interaction of distinct precolonial, Ottoman institutions and colonial policies in shaping postindependence development trajectories deserves far more attention. ${ }^{24}$

\section{Oil and the "Resource Curse"}

A prominent explanation for the relative underdevelopment of MENA countries focuses on the "curse" of oil wealth. ${ }^{25}$ This argument emphasizes the correlation between resource abundance and outcomes such as poor economic performance and unbalanced growth, as well as weak state institutions and authoritarianism, among other ills (Ross 1999). In its economic dimensions, the resource curse centers on the concept of the "Dutch disease," or the theory that an increase in revenues from natural resources will lead to a decline in a country's industrial sector by raising the exchange rate, which makes the manufacturing sector less competitive. Similarly, states that rely on oil or other forms of windfall profits for a large portion of their revenues are deemed "rentier states," which derive their income from nonproductive enterprise. These states concentrate their efforts on distributing wealth to the population, often to buy social peace and preempt greater societal demands for accountability, rather than fostering the conditions for the productive generation of wealth in their societies (Beblawi 1990). 


\section{Development and Underdevelopment in the Middle East and North Africa}

The resource curse provides a compelling explanation for underdevelopment in the Middle East, particularly for the oil-exporting countries. The Gulf states have faced significant challenges in attempting to diversify their economies and indigenize their workforces. A growing body of research, however, qualifies the resource-curse argument, suggesting that it is at best an insufficient and perhaps even not a necessary explanation for underdevelopment. When viewed in larger historical and comparative perspective, resource inflows per se do not necessarily hinder development. Other oil-rich countries such as Norway have managed to escape the alleged inevitability of the resource curse. In the developing world, resource-rich countries such as Indonesia, a major oil exporter (and Muslim-majority country), and Botswana, which has vast mineral deposits, have also managed to attain sustained records of economic growth. Furthermore, longer-run analyses of economic trajectories in the resources-rich economies of the Middle East and North Africa would likely show that these countries were not economically strong even prior to the discovery of oil. Natural resources, then, may reinforce or exacerbated preexisting patterns of development.

Recent studies hold that the timing of the discovery and exploitation of oil in relation to state-building processes shapes how resource wealth affects political and economic development. When oil is exploited in conjunction with the construction of state institutions, it may obviate the need to establish efficient tax bureaucracies because rulers have so much income at their disposal (Smith 2007). Weak state institutions can limit the prospects for economic development, which requires state agencies to direct resources to productive sectors and facilitate investment (Chaudhry 1993; Evans 1995). Other research suggests that ownership structure is a critical factor mediating the effects of oil resources on economic development. Under certain types of private domestic ownership, rather than state control, oil wealth is less likely to weaken state institutions (Jones-Luong and Weinthal 2010).

Critiques based on the timing of oil discovery and ownership structure do not necessarily undercut the validity of the resource-curse argument for the MENA region. In the oil-rich countries, the construction of political institutions generally occurred in conjunction with the exploitation of oil resources, often with substantial foreign influence (Chaudhry 1997; Vitalis 2006). Furthermore, in all MENA countries, the state controls the oil sector.

Other factors provide more compelling reasons to qualify the claim that oil wealth explains economic underperformance among MENA countries. First, to the extent that it is valid, the resource-curse argument only applies to a subset of these economies. Not all countries in the region enjoy large natural resource endowments. Second, recent research on the Gulf oil economies shows that some countries in the region have developed pockets of economic efficiency despite vast natural resource wealth. Within the Gulf countries, some state-owned enterprises are more competitive than others, and some states have experienced greater success in establishing high-performing firms than others within the subregion. As Hertog (2010) argues, the degree of populism and societal penetration of the state, which increase pressure on state officials to use public

Page 18 of 36

PRINTED FROM OXFORD HANDBOOKS ONLINE (www.oxfordhandbooks.com). (c) Oxford University Press, 2015. All Rights Reserved. Under the terms of the licence agreement, an individual user may print out a PDF of a single chapter of a title in Oxford Handbooks Online for personal use (for details see Privacy Policy). 
assets for redistributive purposes and to create jobs, jointly explain why governmentowned firms in countries such as Algeria and Kuwait are less competitive than those in countries such as Saudi Arabia and Qatar.

Oil wealth undoubtedly deterred economic development in at least some MENA countries. Yet a variety of empirical and theoretical critiques of the resource-curse argument convincingly demonstrate that oil wealth is not a sufficient explanation for economic outcomes in the region. Rather, the resource curse may increase the propensity for economic underperformance and exerts a negative impact on growth and development in conjunction with other conditions, such as institutional characteristics and patterns of state-society relations.

\section{Corruption and Crony Capitalism}

Beyond oil, recent analyses emphasize the pervasiveness of corruption and "crony capitalism" in MENA political economies, pointing to poor governance as an explanation for suboptimal economic performance. ${ }^{26}$ Corruption and wasta, or influence and personal connections, are prevalent features of economic and social exchange in the region, particularly in comparison with OECD countries (Heydemann 2004). Inclusive, accountable governance is assumed to produce positive developmental outcomes by increasing popular influence on policy-making, thereby increasing the probability that policies serve the welfare of the people. With growing emphasis on private sector-led development, good governance has attained increased importance. Respect for the rule of law is critical for firms, which require assurances that their assets will not be expropriated and have a chance of reaping good returns before they will invest.

Numerous studies document the alleged "governance gap," or the mismatch between governance and income levels, in the Middle East and North Africa (World Bank 2003b, p. 56), and research on business-government relations in diverse MENA countries documents the prevalence of crony capitalism (Cammett 2007; Catusse 2008; Haddad 2012; Heydemann 2004; Hibou 2006; Leenders 2012; Schlumberger 2008). ${ }^{27}$ Figure 5 depicts regional values of various dimensions of governance, including control of corruption, government effectiveness, rule of law, and voice and accountability. ${ }^{28}$ Like other developing regions, the MENA indeed exhibits poor values in comparison with highincome OECD countries. When benchmarked just against other developing regions, the Middle East performs reasonably well on certain indicators, such as control of corruption, the overall quality of public administration as measured by government effectiveness, and the rule of law. 


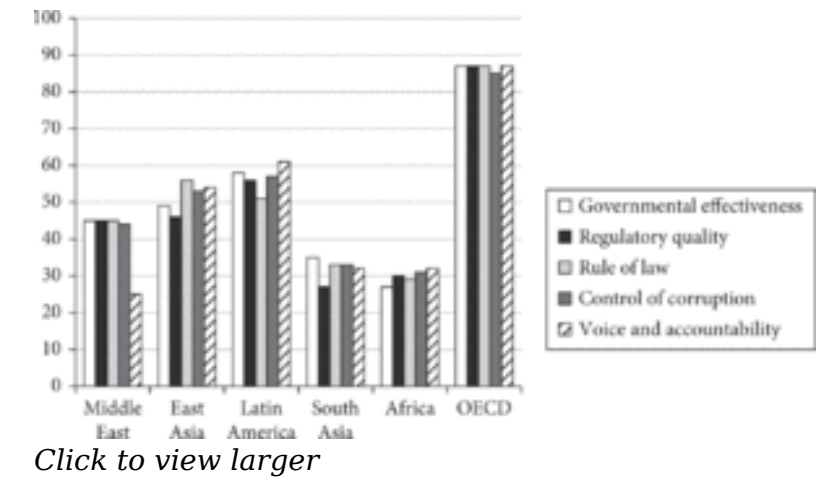

Figure 5: Governance Indicators by Global Region, 2012, Average Percentile Rank

Source: World Bank, “Governance Matters,” 2013.
Research on the impact of corruption and development yields inconclusive results. Some studies question the alleged negative relationship between corruption, on the one hand, and economic growth and development, on the other hand (Kutan, Douglas, and Judge 2009, p. 25). While some

research indicates that corruption hinders development by diverting resources to unproductive endeavors and distorting the economy (Shleifer and Vishny 1993), other analyses maintain that corruption can be economically beneficial under some circumstances by enabling investors to bypass inefficient bureaucratic regulations (Acemoglu and Verdier 1998). Research on the roots of the East Asian "economic miracle" shows that state-business relations were characterized by crony capitalism, yet this did not inhibit countries such as South Korea from achieving spectacular growth rates (Kang 2002). Furthermore, it is difficult to disentangle the interrelationships between corruption and development: It is equally plausible that corruption emerges in the context of poor economic performance.

Aggregate regional scores mask important variation across different types of political economies in the MENA region. Within the region, countries differ in the extent of perceived corruption and the degree to which governments uphold the rule of law. For example, in 2012, the percentile rank of government effectiveness was 83 in the UAE, 56 in Tunisia, 53 in Morocco, 34 in Algeria, and 25 in Egypt. ${ }^{29}$ Likewise, the wealthier countries exhibit lower levels of perceived corruption (83 in the UAE, 53 in Tunisia, 42 in Morocco, 36 in Algeria, and 34 in Egypt) (World Governance Indicators 2012). As would be expected, war-torn and low-income countries such as Iraq, Lebanon, Yemen, and the Palestinian Territories have particularly poor measures, while the Gulf oil monarchies exhibit relatively low levels of corruption and greater respect for the rule of law. Yet some of the region's non-oil economies such as Jordan, Tunisia, and Turkey feature relatively low levels of corruption and greater enforcement of contracts than might be expected (Kaufman, Kraay, and Matruzzi 2009; Sayan 2009, p. 5).

In short, the mere presence of corruption may not provide a convincing explanation for underdevelopment in the Middle East and North Africa. The region as a whole fares relatively well when compared with other regions in the global South, and some of the non-oil countries, which do not exhibit the high income levels associated with better governance, have reasonably good governance scores. More generally, existing social science research finds mixed results for the alleged association between corruption and poor development outcomes; some of the most spectacular economic success stories have 
emerged in the context of widespread cronyism. An important question for future research, then, should focus on the particular nature of corruption and crony capitalism in the MENA countries. Are business-government relations, or other patterns of statesociety relations, especially conducive to suboptimal economic performance at the level of the firm or at higher economic units?

\section{Authoritarianism}

A related but distinct argument links the absence of democracy with poor economic outcomes in the Middle East and North Africa. The region is an outlier with respect to one component of governance- "voice and accountability," or the "extent to which country's citizens are able to participate in selecting their government, as well as freedom of expression, freedom of association, and a free media" (Kaufmann, Kraay, and Mastruzzi 2009) (also see Figure 2). This measure is closely linked to political regime type: Citizens who live in democracies or at least countries with more political freedoms enjoy more basic political and civil liberties. ${ }^{30}$

Authoritarianism is sometimes linked to poor economic performance in the region (UNDP 2002, 2003, 2004; Henry and Springborg 2010; World Bank 2003b, pp. 70-71). The relative dearth of political freedom and failure to uphold the rule of law inhibit the formulation and implementation of policies that benefit the public good, rather than private interests (UNDP 2002). For example, Henry and Springborg (2010) argue that authoritarianism and the related lack of transparency in the political economies of the region are major obstacles to attracting foreign investment and spurring domestic capital holders to make long-term investments. Insecure property rights, which can arise in authoritarian systems in which rulers are relatively unchecked, may deter the levels of private and foreign investment needed to sustain economic growth and ultimately inhibit further integration of MENA countries in the global economy. Furthermore, political repression inhibits labor and other social groups from organizing in defense of their interests and makes private-capital holders hesitant to initiate new projects and undertake long-term investment. Middle Eastern and North African governments maintain their hold on power through a combination of carrots and sticks. In the oildependent economies, governments compensate for limited accountability by providing public goods and social services to maintain citizen satisfaction. In the poorer, non-oil economies, elites with close ties to rulers profit from limited accountability in the system to maintain their privileged access to economic opportunities. These strategies can lead to poor developmental outcomes in the long run.

Arguments linking authoritarianism and lack of transparency with relative underdevelopment in the MENA region are compelling but not entirely convincing. Research on the relationship between regime type and economic development is inconclusive (Przeworski 2004), and empirical evidence from other regions, notably East Asia, suggests that authoritarian rule can be compatible with development. The case of South Korea is illustrative. In the 1970s and 1980s, South Korea experienced double-digit 
growth rates and rapid economic development. This remarkable transition, which has served as a model for developing countries across the globe, occurred in the context of authoritarian rule, political repression, and corruption (Deyo 1989; Kang 2002).

Furthermore, even if aspects of authoritarianism impede development, the origins of related factors in Middle Eastern political economies-that is, corruption, the lack of transparency, and weak state institutions-deserve more systematic analysis. Effective extractive, regulatory, and administrative institutions are critical to development (Evans 1995; Kohli 2004; Lange and Rueschemeyer 2005), yet little research explores the origins of effective and ineffective state institutions in the MENA region. As I argue in the next section, the precise impact of Ottoman and colonial institutions on the evolution of state institutions and forms of economic management in postindependence states deserves more scholarly attention.

\section{Populism and State-Society Relations}

The political elites who took power in newly independent countries made economic and social policy choices that shaped development paths in more recent decades, even if the institutions they inherited from colonial authorities constrained national economic trajectories. In the context of anticolonial backlash and the emphasis on ISI development strategies in the global South in the 1950s and 1960s, most MENA governments adopted variants of populist policies and statist approaches, which may have harmed longer-term growth prospects. Although natural resource abundance does not determine economic policy choices, windfall profits from oil wealth also contributed to poor economic performance in indirect ways via foreign aid and remittances from the Gulf states to lower-income countries. Thus, a combination of postindependence nationalist fervor, the dominant economic wisdom at the time, and regional capital flows facilitated the establishment of an "interventionist-redistributive" development approach (Youssef 2004, p. 92). This model is characterized by redistribution and equity in economic and social policy, precedence for state planning over market-based allocation, protectionism, a dominant state role in the provision of welfare and social services, and the suppression of contestation in the political arena (World Bank 2003b, p. 2). Once established, social contracts were virtually impossible to dismantle even when they became economically unsustainable, locking MENA countries into inefficient patterns of resource allocation.

Why then did postcolonial leaders adopt populist policies across the Middle East and North Africa? An answer to this question requires a political sociological approach. Based on a comparison of state-building in the Middle East and East Asia, Waldner (1999) contends that divisions within the political elite compelled policy-makers in Turkey and Syria to make greater concessions or "side payments" to the popular classes than in South Korea and Taiwan, where more narrow, cohesive social coalitions enabled rulers to adopt less redistributive policies that promoted investment and growth. 
The social contract hypothesis provides a powerful explanation for the decline of economic growth in the MENA region in the 1980s onward, when recession and falling oil prices drastically cut resource flows in the region and debt burdens soared. This approach also points to many of the challenges that currently plagues efforts to bring about structural reforms across the region. Arguments in this vein are most convincing when they acknowledge and aim to account for variation in the nature of social contracts. As discussed above, in the first decades after independence, different countries in the MENA region established distinct types of political economies with varied strategies of legitimation. Both economic factors, notably oil endowments, and political factors, such as regime type and the social origins and commitments of postindependence elites, shaped the diverse bargains between rulers and ruled in MENA countries and, potentially, citizen expectations of their states. More attention to the distinct types of social contracts in the region, and the bargains between rulers and ruled that underpin them, would help to explain why some states appear to remain more locked in than others to these arrangements. This kind of political sociological approach, which acknowledges cross-national variation, is a promising foundation for ongoing research on economic trajectories and performance in the region.

\section{Research Agenda}

The diverse explanations reviewed in this chapter make valuable contributions to an understanding of the political economy of development in the Middle East and North Africa; however, many of these approaches are best viewed in probabilistic terms or as factors that interact with other conditions to shape economic-development trajectories. Some approaches also suffer from internal inconsistencies or encounter empirical contradictions. Analyses that highlight the long-term roots of underdevelopment in the Muslim world usefully integrate MENA cases directly into debates about the historical determinants of growth and development (Blaydes and Chaney 2013; Kuran 2011). A long-run historical perspective is compelling because variation in rates of economic development can be due to short-term factors such as natural disasters, business cycles, and public policies, whereas long-term economic development trends have much deeper roots (Mahoney 2010, pp. 7-8). At the same time, deeply historical accounts must be contextualized to highlight variation over time and space and to point to the political contests that shaped the formation and reproduction of institutions both centuries ago and in the more recent past. Economic historians of the MENA region have documented differences in Islamic economic and social institutions as well as flexibility in the functioning of charitable trusts (awqaf) and forms of corporate ownership, pointing to the merits of research on specific places rather than the Islamic world as a whole. Thus, ongoing research on the impact of Ottoman-era institutions on development should take seriously variation in the ways in which the same institutions were actually implemented in different parts of the Muslim world. Furthermore, while Ottoman state practices or styles of governance might have had a greater causal impact on development trajectories 


\section{Development and Underdevelopment in the Middle East and North Africa}

than Islamic institutions (Çizakça 2010; Goldstone 2012), future scholarship should assess patterns of institutional reproduction and change in more recent centuries and explore the interaction of institutions established over centuries ago with more recent developments during the colonial and postcolonial eras.

Turning to the postindependence period, variation in development trajectories within the MENA region is a crucial starting point for further research. The region is characterized by markedly distinct types of political economies, which are shaped in part by different levels of labor and natural resources endowments. To seek the origins of distinct economic trajectories, comparisons between this region and relevant countries from other developing regions are a promising strategy. Cross-regional research should compare the MENA region with South Asia or sub-Saharan Africa, which have more comparable histories of colonialism and postcolonial development policies and politics, rather than the exceptional cases of East Asia (Owen 2002). Given shared histories of ISI followed by state retrenchment, comparisons between the labor-abundant MENA countries with some Latin American countries would also be fruitful. Few developing countries have achieved sustained high growth rates and levels of industrialization in the twentieth century outside of the East Asian countries, such as South Korea and Taiwan.

More intra-regional comparisons would also be valuable. While it is true that many MENA countries share similar records of underdevelopment, there are important areas of variation, including within the oil and non-oil subtypes of economies. An obvious comparison is between Turkey, the seat of the former Ottoman Empire and an economic "success story" in the past few decades, and non-oil Arab countries such as Egypt or Tunisia, which also pursued industrialization as a path to development. What explains Turkey's ability to achieve high growth rates while other countries that also developed their industrial sectors, including through export-led industrialization, have faltered? Why were Turkish elites able to change course more successfully than other countries in the region and in the global South? These kinds of questions require attention to the politics behind shifts in economic strategies and the resultant changes in development trajectories. The ruling Islamist Justice and Development Party (AKP) often receives credit for high growth rates in Turkey since the 1990s, but its main constituents-pious, export-oriented businesspeople in central Anatolia-were in fact beneficiaries of policies adopted in an earlier period by a non-Islamist ruling party (Gumuscu 2012). A full account of how Turkey managed to alter its development trajectory so dramatically in the past few decades requires a political account of how Turkey policy-makers were able to implement policies that threatened influential protectionist interests and dismantled populist policies while introducing new kinds of poverty-alleviation strategies.

A key frontier in research on the political economy of development aims to locate the origins of distinct development paths and their relationships with different patterns of economic growth (Sen 2013). This kind of approach requires careful attention to the political struggles and social bargains underlying institutional formation and change. A focus on the dynamics of state-building in the postcolonial periods, as found in Waldner's (1999) work, is a good starting point. To understand the origins of distinct development 
paths in the region, future research should dig even more deeply by tracing who gained power in postindependence governments, the kinds of bargains established between the new leadership and key societal actors, what kinds of institutions and policies arose from the interactions of rulers and ruled, and how these arrangements changed over time. Systematic and appropriate cross-national and cross-regional comparative analyses of the political determinants of different economic paths are a promising starting point for ongoing research on the political economy of development in the MENA region.

The need for rigorous research on development in the region is all the more important in the contemporary period. As the Arab uprisings have exposed, high levels of youth unemployment, particular among educated youth, is a major challenge for most MENA countries. How have and how will these countries craft their economic and social policies in the years to come? How will their institutional histories, which embody decades if not centuries of political struggles, shape varied approaches? Furthermore, political change in Tunisia, Egypt, and, possibly, Libya and other Arab countries potentially constitutes a genuine "critical juncture" for economic and social policy formulation. The Arab uprisings, while still unfolding in most countries, have enabled more and different voices to be heard in the political arena and, as a result, may lead to substantive policy shifts in the future.

\section{Acknowledgments}

I thank Bryan Daves, Ishac Diwan and Roger Owen for comments on drafts of this essay. All errors are my own.

\section{References}

Abu-Lughod, Lila (2009). “Dialects of Women's Empowerment: The International Circuitry of the Arab Human Development Report 2005." International Journal of Middle East Studies 41(1): 83-103.

Acemoglu, Daron, Simon Johnson, and James A Robinson (2002). "Reversal of Fortune: Geography and Institutions in the Making of the Modern World Income Distribution." Quarterly Journal of Economics 117(4): 1231-1294.

Acemoglu, Daron, Simon Johnson, and James A Robinson. (2005). "Institutions as a Fundamental Cause of Long-Run Growth." Handbook of Economic Growth 1: 385-472.

Acemoglu, Daron, and Thierry Verdier (1998). "Property Rights, Corruption and the Allocation of Talent: A General Equilibrium Approach.” Economic Journal 108(450): 13811403. 
Bayat, Asef (2005). "Transforming the Arab World: The Arab Human Development Report and the Politics of Change." Development and Change 36(6): 1225-1237.

Beblawi, Hazem (1987). "The Rentier State in the Arab World." In The Rentier State, ed. Hazem Beblawi and Giacomo Luciani. 85-98. London: Croom Helm.

Beblawi, Hazem, and Giacomo Luciani (1987). The Rentier State in the Arab World. London: Croom Helm.

Beblawi, Hazem (1990). “The Rentier State in the Arab World.” In Giacomo Luciani (ed.), The Arab State. London: Routledge.

Bellin, Eva (2002). Stalled Democracy: Capital, Labor, and the Paradox of StateSponsored Development. Ithaca, NY: Cornell University Press.

Bellin, Eva (2004). “The Robustness of Authoritarianism in the Middle East: Exceptionalism in Comparative Perspective." Comparative Politics 36(2): 139-57.

Blaydes, Lisa, and Eric Chaney (2013). "The Feudal Revolution and Europe's Rise: Political Divergence of the Christian West and the Muslim World before 1500 CE." American Political Science Review 107(1): 16-34.

Boone, Catherine (1994). "States and Ruling Classes in Postcolonial Africa: The Enduring Contradictions of Power." In State Power and Social Forces: Domination and

Transformation in the Third World, ed. Joel Migdal, Atul Kohli, and Vivian Shue. 108-140. New York: Cambridge University Press.

Cammett, Melani (2007). Globalization and Business Politics in Arab North Africa: A Comparative Perspective. New York: Cambridge University Press.

Cammett, Melani, and Ishac Diwan (2013). "A Political Economy of the Arab Uprisings." In A Political Economy of the Middle East, ed. Alan Richards and John Waterbury. Boulder, CO: Westview.

Cammett, Melani, and Ishac Diwan (2014). A Political Economy of the Middle East. 4th ed. Boulder, CO: Westview.

Cammett, Melani, and Marsha Pripstein Posusney (2010). "Labor Standards and Labor Flexibility in the Middle East: Freer Trade and Freer Unions?" Studies in Comparative International Development 45(2): 250-279.

Catusse, Myriam (2008). Le Temps des Entrepreneurs? Politique et Transformations du Capitalisme au Maroc. Paris: Maisonneuve \& Larose.

Chaudhry, Kiren Aziz (1993). "The Myths of the Market and the Common History of Late Developers." Politics and Society 21(3): 245-274. 
Chaudhry, Kiren Aziz (1997). The Price of Wealth: Economies and Institutions in the Middle East. Ithaca, NY: Cornell University Press.

Chekir, Hamouda, and Ishac Diwan (2013). "Distressed Whales on the Nile-Egypt Capitalists in the Wake of the 2010 Revolution." CID working paper, no. 250. Cambridge, MA: Center for International Development, Harvard University.

CIA (2013). "Yemen." The World Factbook. Washington, DC: Central Intelligence Agency. Available at https://www.cia.gov/library/publications/the-world-factbook/geos/ ym.html. Accessed October 21, 2013.

Çizakça, Murat (2010). “Was Shari'ah Indeed the Culprit?” MPRA working paper. Kuala Lumpur: International Centre for Education in Islamic Finance (INCEIF).

Crystal, Jill (1995). Oil and Politics in the Gulf. New York: Cambridge University Press.

Deyo, Frederic C (1989). Beneath the Miracle: Labor Subordination in the New Asian Industrialism. Berkeley: University of California Press.

Diamond, Jared M, and Doug Ordunio (1997). Guns, Germs, and Steel. New York: Norton. Diamond, Larry (2010). “Why Are There No Arab Democracies?” Journal of Democracy 21(1): 93-112.

Engerman, Stanley L, and Kenneth L Sokoloff (2002). Factor Endowments, Inequality, and Paths of Development among New World Economics. Cambridge, MA: National Bureau of Economic Research.

Evans, Peter (1995). Embedded Autonomy: States and Industrial Transformation. Princeton, NJ: Princeton University Press.

Gates, Carolyn L (1998). The Merchant Republic of Lebanon: Rise of an Open Economy. London: I.B. Tauris.

Geddes, Barbara (1999). “What Do We Know about Democratization after Twenty Years?” Annual Review of Political Science 2 (1): 115-144.

Gobe, Eric (1999). Les hommes d'affaires egyptiens: Democratisation et secteur prive dans l'Egypte de l'Infitah. Paris: Karthala.

Goldstone, Jack A (2012). “Is Islam Bad for Business?” Perspectives on Politics 10(1): 97102.

Greif, Avner (2006). Institutions and the Path to the Modern Economy: Lessons from Medieval Trade. New York: Cambridge University Press.

Gumuscu, Sebnem (2012). “Egypt Can't Replicate the Turkish Model: But It Can Learn From It." Sada. Available at http://carnegieendowment.org/sada/?fa=46454. 
Haddad, Bassam. 2004. "The Formation and Development of Economic Networks in Syria: Implications for Economic and Fiscal Reforms, 1986-2000". In Steven Heydemann, ed. Networks of Privilege in the Middle East: The Politics of Economic Reform Revisited. 3776. New York: Palgrave Macmillan.

Haddad, Bassam (2012). Business Networks in Syria: The Political Economy of Authoritarian Resilience. Stanford, CA: Stanford University Press.

Haj, Samira (1997). The Making of Iraq, 1900-1963: Capital, Power, and Ideology. Albany: State University of New York Press.

Henry, Clement Moore, and Robert Springborg (2010). Globalization and the Politics of Development in the Middle East. Vol. 1. Cambridge: Cambridge University Press.

Herb, Michael (1999). All in the Family: Absolutism, Revolution, and Democracy in Middle Eastern Monarchies. Albany, NY: State University of New York Press.

Hertog, Steffen (2010). Princes, Brokers, and Bureaucrats: Oil and the State in Saudi Arabia. Ithaca, NY: Cornell University Press.

Heydemann, Steven (2004). Networks of Privilege in the Middle East: The Politics of Economic Reform Revisited. New York: Palgrave Macmillan.

Hibou, Beatrice (2006). La Force de L'Obeissance: Economic Politique de la Repression en Tunisie. Paris: Editions de la Decouverte.

Ibrahim, Ahmed Fekry (2011). "Review of Timur Kuran, The Long Divergence: How Islamic Law Held Back the Middle East, (Princeton: Princeton University Press, 2010)." New Middle Eastern Studies 1: 1-3.

ILO (2010). World of Work Report 2010: From One Crisis to the Next? Geneva: International Labour Organization.

ILO (2011). World of Work Report 2011: Making Markets Work for Jobs. Geneva: International Labour Organization.

IMF (2013). “World Economic Outlook Database.” Washington, DC: International Monetary Fund.

Jones Luong, Pauline, and Weinthal (2010). Oil Is Not a Curse: Ownership Structure and Institutions in Soviet Successor States. Cambridge: Cambridge University Press.

Kang, David (2002). Crony Capitalism: Corruption and Development in South Korea and the Philippines. Cambridge: Cambridge University Press.

Kapiszewski, Andrzej (2006). “Arab versus Asian Migrant Workers in the GCC Countries.” In United Nations Expert Group Meeting on International Migration and Development in the Arab Region. Beirut: United Nations Secretariat. 


\section{Development and Underdevelopment in the Middle East and North Africa}

Karpat, Kemal H (2010). Elites and Religion from Ottoman Empire to Turkish Republic. Vol. 1. Istanbul: Timas Publishing Group.

Karshenas, Massoud, and Valentine M. Moghadam (2006). Social Policy in the Middle East: Economic, Political, and Gender Dynamics. New York: United Nations Research Institute for Social Development and Palgrave Macmillan.

Kaufmann, Daniel, Aart Kraay, and Massimo Mastruzzi (2009). “Governance Matters VIII: Aggregate and Individual Governance Indicators, 1996-2008." World Bank policy research working paper, no. 4978. Washington, DC: World Bank.

Kohli, Atul (2004). State-Directed Development: Political Power and Industrialization in the Global Periphery. New York: Cambridge University Press.

Kuran, Timur (2003). "The Islamic Commercial Crisis: Institutional Roots of Economic Underdevelopment in the Middle East." Journal of Economic History 63(2): 414-446.

Kuran, Timur (2004). "Why the Middle East Is Economically Underdeveloped: Historical Mechanisms of Institutional Stagnation." Journal of Economic Perspectives 18(3): 71-90.

Kuran, Timur (2011). The Long Divergence: How Islamic Law Held Back the Middle East. Princeton, NJ: Princeton University Press.

Kutan, Ali M., Thomas J. Douglas, and William Q. Judge (2009). “Does Corruption Hurt Economic Development? Evidence from Middle Eastern, North African and Latin American Countries." In Economic Performance in the Middle East and North Africa: Institutions, Corruption and Reform, ed. S. Sayan, 25-37. London: Routledge.

Lange, Matthew (2009). Lineages of Despotism and Development: British Colonialism and State Power. Chicago: University of Chicago Press.

Lange, Matthew, and Dietrich Rueschemeyer (2005). States and Development: Historical Antecedents of Stagnation and Advance. New York: Palgrave Macmillan.

Leenders, Reinoud (2012). Spoils of Truce: Corruption and State-Building in Post-War Lebanon. Ithaca, NY: Cornell University Press.

Leveau, Remy (1985). Le fellah Marocain: Defenseur du trone. Paris: Fondation Nationale des Sciences Politiques.

Lewis, Bernard (1982). The Muslim Discovery of Europe. New York: W.W. Norton.

Maddison, Angus (2003). The World Economy: Historical Statistics. Development Centre Studies. Paris: OECD Publishing.

Mahoney, James (2010). Colonialism and Postcolonial Development: Spanish America in Comparative Perspective. Cambridge: Cambridge University Press. 
Malik, Khalid. (2013). "Human development report 2013. The rise of the South: Human progress in a diverse world." The Rise of the South: Human Progress in a Diverse World (March 15, 2013). UNDP-HDRO Human Development Reports.

Mamdani, Mahmood (1996). Citizen and Subject. Cambridge: Cambridge University Press.

Moore, Pete (2004). Doing Business in the Middle East: Politics and Economic Crisis in Jordan and Kuwait. Cambridge: Cambridge University Press.

Murphey, Rhoads (1999). Ottoman Warfare, 1500-1700. New Brunswick, NJ: Rutgers University Press.

Noland, Marcus, and Howard Pack (2007). The Arab Economies in a Changing World. Washington, DC: Peterson Institute for International Economics.

North, Douglass C (1990). Institutions, Institutional Change, and Economic Performance. Cambridge: Cambridge University Press.

Nugent, Jeffrey B., and M. Hashem Pesaran (2007). "Introduction: Explaining Growth in the Middle East." In Explaining Growth in the Middle East, ed. Jeffrey B Nugent and M. Hashem Pesaran. 1-27. Oxford: Elsevier.

Owen, Roger (1992). State, Power and Politics in the Making of the Modern Middle East. London: Routledge.

Owen, Roger (1993). The Middle East in the World Economy, 1800-1914. London: I.B. Tauris.

Owen, Roger (2002). "The Uses and Abuses of Comparison: Why Set Egypt against South Korea?" Al Ahram Weekly Online. January 2.

Owen, Roger, and Sevket Pamuk (1999). A History of Middle East Economies in the Twentieth Century. Cambridge, MA: Harvard University Press.

Pamuk, Şevket (1992). "Anatolia and Egypt during the Nineteenth Century: A Comparison of Foreign Trade and Foreign Investment." New Perspectives on Turkey 7: 37-55.

Pamuk, Şevket (2006). “Estimating economic growth in the Middle East since 1820.” Journal of Economic History 66(3): 809-828.

Pfeifer, Karen (2012). “Gulf Arab Financial Flows and Investment, 2000-2010: Promises, Process, and Prospects in the MENA Region." Review of Middle East Economics and Finance 8(2): 3-38.

Posusney, Marsha Pripstein, and Michele Penner Angrist (2005). Authoritarianism in the Middle East: Regimes and Resistance. Boulder, CO: Lynne Rienner. 
Pryor, Frederic (2006). "The Economic Impact of Islam on Developing Nations.” Available at SSRN 929104.

Przeworski, Adam (2004). “Democracy and Economic Development." In The Evolution of Political Knowledge. Democracy, Autonomy, and Conflict in Comparative and

International Politics, ed. E. D. Mansfield and R. Sisson. 300-324. Columbus: Ohio State University Press.

Richards, Alan, and John Waterbury. (1996). A Political Economy of the Middle East, Boulder. CO: Westview Press.

Richards, Alan, and John Waterbury (2008). A Political Economy of the Middle East. 3rd ed. Boulder, CO: Westview.

Rivlin, Paul (2001). Economic Policy and Performance in the Arab World. Boulder, CO: Lynne Rienner.

Rodinson, Maxime (1978). Islam and Capitalism. Austin: University of Texas Press.

Ross, Michael (2012). The Oil Curse: How Petroleum Wealth Shapes the Development of Nations. Princeton, NJ: Princeton University Press.

Ross, Michael L (1999). "The Political Economy of the Resource Curse.” World Politics 51(2): 297-322.

Ross, Michael Lewin (2001). “Does Oil Hinder Democracy?” World Politics 53(3): 325361.

Ryan, Curtis R (2002). Jordan in Transition: From Hussein to Abdullah. Boulder, CO: Lynne Rienner.

Sachs, Jeffrey D., and Andrew M. Warner (1997). "Fundamental Sources of Long-Run Growth." American Economic Review 87(2): 184-188.

Sachs, Jeffrey D., and Andrew M. Warner (2001). "The Curse of Natural Resources." European Economic Review 45: 827-838.

Salehi-Isfahani, Djavad (2010). "Human Development in the Middle East and North Africa." Human Development: 26.

Sayan, Serdar (2009). Economic Performance in the Middle East and North Africa: Institutions, Corruption, and Reform. London. Routledge.

Schlumberger, Oliver (2008). "Structural Reform, Economic Order, and Development: Patrimonial Capitalism." Review of International Political Economy 15(4): 622-649.

Sen, Amartya (1999). Development as Freedom. New York: Anchor. 
Sen, Kunal (2013). "The Political Dynamics of Economic Growth." World Development 47: 71-86.

Sfakianakis, John (2004). "The Whales of the Nile: Networks, Businessmen and Bureaucrats during the Era of Privatization in Egypt." In Networks of Privilege: Rethinking the Politics of Economic Reform in the Middle East, ed. Steven Heydemann. 77-91. New York: Palgrave Macmillan.

Shleifer, Andrei, and Robert W. Vishny (1993). “Corruption.” Quarterly Journal of Economics 108(3): 599-617.

Smith, Benjamin (2007). Hard Times in the Lands of Plenty: Oil Politics in Iran and Indonesia. Ithaca, NY: Cornell University Press.

UNDP (1994). Human Development Report 1994: New Dimensions of Human Security. New York: United Nations Development Programme.

UNDP (2002). Arab Human Development Report 2002: Creating Opportunities for Future Generations. New York: United Nations Development Programme.

UNDP (2003). Arab Human Development Report 2003: Building a Knowledge Society. United Nations Publications.

UNDP (2004). Arab Human Development Report 2004: Towards Freedom in the Arab World. New York: United Nations Development Programme.

UNDP (2009). Arab Human Development 2009: Challenges to Human Security in the Arab Countries. New York: United Nations Development Programme.

Vitalis, Robert (2006). America's Kingdom: Mythmaking on the Saudi Oil Frontier. Stanford, CA: Stanford University Press.

Waldner, David (1999). State Building and Late Development. Ithaca, NY: Cornell University Press.

Weber, Max (1978). Economy and Society, ed. Guenther Roth and Claus Wittich. Berkeley: University of California Press.

Weber, Max (2009). From Max Weber: essays in sociology. Routledge.

World Bank (2003a). Better Governance for Development in the Middle East and North Africa: Enhancing Inclusiveness and Accountability. Washington, DC: World Bank.

World Bank (2003b). Unlocking the Employment Potential in the Middle East and North Africa: Toward a New Social Contract. Washington, DC: World Bank.

World Bank (2011). Doing Business 2011: Measuring Business Regulations. Washington, DC: World Bank. Available at http://www.doingbusiness.org/custom-query. 
World Bank (2013). World Development Indicators 2013. Washington, DC: World Bank. Available at http://data.worldbank.org/data-catalog/world-development-indicators/ wdi-2013.

World Governance Indicators (2012). http://data.worldbank.org/data-catalog/ worldwide-governance-indicators.

Yousef, Tarik M. (2004). "Development, Growth and Policy Reform in the Middle East and North Africa since 1950.” Journal of Economic Perspectives 18(3): 91-116.

Zartman, I. William (1990). “Opposition as Support of the State.” In The Arab State, ed. Giacomo Luciani. 220-246. London: Routledge.

\section{Notes:}

( ${ }^{1}$ I focus primarily on the oil states of the Gulf (i.e., Bahrain, Kuwait, Oman, Qatar, Saudi Arabia, the United Arab Emirates and Yemen, which recently attained the status of an oil producer), the countries of the Levant (i.e., Jordan, Lebanon and Syria), the main North African countries (i.e., Algeria, Morocco and Tunisia), Turkey and Iran. I exclude Israel because its economic structure and unique history make its political economy more comparable to that of the OECD states; and the sub-Saharan Arab countries such as Djibouti, Mauritania, and Sudan, which are sometimes included in the region because they are members of the Arab League. The chapter does not address the cases of Palestine and Iraq in detail, which have both experienced significant "dedevelopment" (Roy 1995) due to protracted conflict and foreign occupation.

$\left({ }^{2}\right)$ For a detailed breakdown of distinct subregional patterns of economic growth, see Cammett and Diwan (2014).

$\left({ }^{3}\right)$ The UNDP's HDI provides an aggregate measure of the living conditions of the population across different countries and includes measures of health and access to health care services, nutrition levels, life expectancy at birth, adult literacy and mean years of schooling, access to basic infrastructure such as water and sanitation, real per capita income adjusted for the differing purchasing power parity of each country's currency, and the percentage of the population living below the poverty line.

$\left({ }^{4}\right)$ I am grateful to Ishac Diwan for emphasizing this point.

$\left({ }^{5}\right)$ In 2009, female labor force participation rates were $24.8 \%$ in the Middle East, $27.6 \%$ in North Africa, 39.6\% in South Asia, 52\% in Latin America, 57.6\% in Southeast Asia, $61.3 \%$ in sub-Saharan Africa, and 66.5\% in East Asia (ILO 2011).

$\left({ }^{6}\right)$ The World Bank classifies Libya as an upper middle income country. 
$\left({ }^{7}\right)$ I define oil dependency as a ratio of fuel exports to total export earnings of more than $66 \%$, moderate dependency as a ratio between $34 \%$ and $65 \%$, and low dependency as less than $33 \%$. The UAE recently shifted to "moderate" oil dependence, which largely reflects the growing importance of financial services and related sectors in the federation's economies.

$\left(^{8}\right)$ I discuss the Dutch disease argument below.

$\left({ }^{9}\right)$ A dominant economic interpretation defines institutions as the basic rules of an economy, including formal systems, such as constitutions, laws, taxation, insurance, and market regulations, as well as informal norms of behavior, such as habits, customs, and ideologies (North 1990). Note that institutional quality is distinct from regime type. For example, some democracies do not guarantee property rights more than some authoritarian regimes.

$\left({ }^{10}\right)$ When these policies were initiated, many republics were allied with the Soviet Union, which helped to inspire the adoption of planning and the expansion of the public sector.

(11) At various times, Kuwait and Bahrain have effectively permitted parties to operate by allowing organized groups to field candidates in elections (Cammett and Posusney 2010).

(12) In 2011, only Tunisia ranked higher than some of the Gulf oil monarchies (Kuwait and Oman) in the ease of doing business (World Bank 2011).

(13) The two non-oil monarchies diverge with respect to the adoption of ISI as a development strategy. Jordan's small size and limited resource base precluded the adoption of domestically oriented trade policies, and the country's strategic value has enabled it to become heavily aid dependent. In Morocco, which has a larger population and agricultural base, ISI was adopted wholeheartedly beginning in the 1960s and consolidated in the 1970s.

(14) Economic crisis does not fully explain the turn to the assistance of international financial institutions (Owen 1992, pp. 139-141). Some countries such as Tunisia initiated partial liberalizations of their economies well before experiencing a crisis. Furthermore, the region as a whole had more revenues thanks to oil and regional labor remittances than other developing regions such as Latin America and sub-Saharan Africa. These sources of wealth could have enabled many MENA countries to stave off painful economic reforms for a longer period. Although the Gulf oil monarchies had never adopted protectionist trade regimes, the oil price slumps of the mid-1980s compelled some to institute austerity programs and to seek to diversity their economies and "indigenize" their work forces (Kapiszewski 2006).

$\left({ }^{15}\right)$ Data on inequality are notoriously unreliable and may underreport the actual extent of income inequality in the region. 


\section{Development and Underdevelopment in the Middle East and North Africa}

$\left({ }^{16}\right)$ For a critique of Weber's arguments vis-à-vis Islam and capitalism, see Rodinson (1978).

$\left({ }^{17}\right)$ Goldstone (2012) elaborates this argument in detail in his review of Kuran's most recent book (2010).

(18) Kuran (2011, p. 15) himself acknowledges another potential critique of his argument, notably that it contains elements of endogeneity. By adopting a particular historical moment from which to begin the analysis of the economic decline of the Islamic world, it is not clear whether institutional rigidity caused economic stagnation or vice versa (Ibrahim 2011, pp. 2-3). Still, most claims in the social sciences are subject to some forms of endogeneity, whether through omitted variable bias, reverse or reciprocal causation, or some other factor, and yet make important contributions.

(19) I am grateful to Beshara Doumani, Tarek Masoud, and Roger Owen for input on these points.

$\left({ }^{20}\right)$ To be fair, these arguments do not entirely undercut the claim that Islamic institutions deter economic growth: The alleged negative effects of Islamic institutions may be counterbalanced by the positive impact of other Islamic or non-Islamic institutions in MENA countries or convergence in institutions and policies in recent decades may have diminished the negative effects of Islamic institutions on development.

(21) This section draws on Owen and Pamuk (1999).

$\left.{ }^{22}\right)$ During the Great Depression, however, increased protectionism enabled more local investors to establish manufacturing enterprises.

(23) Iran was occupied by British, American, and Soviet forces during World War II.

(24) Similarly, Mahoney (2010) argues convincingly that precolonial institutions are an integral part of explanations for postindependence state effectiveness in Latin America.

$\left({ }^{25}\right)$ A large body of research directly and indirectly links oil wealth to authoritarianism in the region (see, inter alia, Beblawi and Luciani 1987; Bellin 2004; Chaudhry 1997; Crystal 1995; Ross 2001). I do not address this literature in this review, which focuses on the economic rather than political ramifications of rentierism.

$\left({ }^{26}\right)$ As the World Bank (2003a, p. xviii) holds that "public governance is good when this process is inclusive of everyone and when the people can hold accountable those who make and implement the rules."

(27) Through an analysis of firm valuations before and after the Egyptian revolution, Chekir and Diwan (2013) show the market value of political connections in Egypt, indicating that connected firms were not the most high performing firms but rather benefited disproportionately from their ties to political elites. 
(28) According to the Governance Matters Dataset (Kaufman, Kraay, and Mastruzzi 2009), "control of corruption" measures the extent to which public power is exercised for private gain; "government effectiveness" measures the quality of public services, the quality of the civil service and the degree of its independence from political pressures, the quality of policy formulation and implementation, and the credibility of the government's commitment to such policies; and "rule of law" measures the extent to which agents have confidence in and abide by the rules of society, such as contract enforcement, the police, and the courts, as well as the likelihood of crime and violence.

(29) In 2009, the year before the uprising, Tunisia had a score of 66, and Egypt had a score of 47 for government effectiveness.

$\left({ }^{30}\right)$ Multiple other sources point to the disproportionate presence of authoritarian regimes in the Middle East and North Africa (Diamond 2010; Geddes 1999).

\section{Melani Cammett}

Melani Cammett is Professor of Government at Harvard University and a Faculty Affiliate at the Belfer Center's Middle East Initiative.

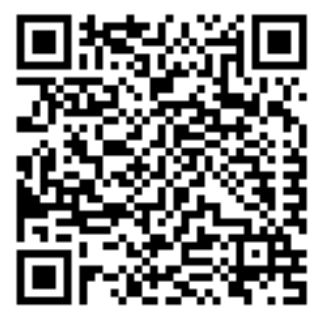

